This item was submitted to Loughborough's Research Repository by the author.

Items in Figshare are protected by copyright, with all rights reserved, unless otherwise indicated.

\title{
Loess geohazards research in China: Advances and challenges for mega engineering projects
}

\section{PLEASE CITE THE PUBLISHED VERSION}

https://doi.org/10.1016/j.enggeo.2019.01.019

\section{PUBLISHER}

(c) Elsevier

VERSION

AM (Accepted Manuscript)

\section{PUBLISHER STATEMENT}

This paper was accepted for publication in the journal Engineering Geology and the definitive published version is available at https://doi.org/10.1016/j.enggeo.2019.01.019

\section{LICENCE}

CC BY-NC-ND 4.0

\section{REPOSITORY RECORD}

Juang, C. Hsein, Tom Dijkstra, Janusz Wasowski, and Xingmin Meng. 2019. "Loess Geohazards Research in China: Advances and Challenges for Mega Engineering Projects". Loughborough University.

https://hdl.handle.net/2134/37278. 


\title{
Loess geohazards research in China: Advances and challenges for mega engineering projects
}

\author{
C. Hsein Juang ${ }^{1 *}$, Tom Dijkstra ${ }^{2}$, Janusz Wasowski ${ }^{3}$, and Xingmin Meng ${ }^{4}$ \\ ${ }^{1}$ Department and Civil Engineering and Graduate Institute of Applied Geology, National Central \\ University, Taoyuan City 32001, Taiwan. [Email: hsein@ clemson.edu] \\ ${ }^{2}$ School of Architecture, Building and Civil Engineering, Loughborough University, LE11 3TU, \\ UK. [Email: t.a.dijkstra@lboro.ac.uk] \\ ${ }^{3}$ National Research Council, Institute for Geohydrological Protection, via Amendola 122 I, 70126 \\ Bari, Italy. [Email: j.wasowski@ba.irpi.cnr.it] \\ ${ }^{4}$ School of Earth Sciences, Lanzhou University, Lanzhou 730000, China. [Email: \\ xmmeng@1zu.edu.cn] \\ *Corresponding author: C. H. Juang (hsein@ clemson.edu)
}

\begin{abstract}
Loess is a meta-stable, cemented assemblage of mainly silt and clay-sized particles of low plasticity. When dry it behaves like a brittle material, but when wetted up the fabric rapidly collapses. Unique geomorphological features include extensive surface erosion, soil piping (loess 'karst'), catastrophic landslides, and widespread collapse (hydro-consolidation). The Chinese Loess Plateau is a more or less continuous drape of thick loess covering some $440,000 \mathrm{~km}^{2}$. It isone of China's regions that is most prone to geohazards. This paper reviews advances in the research related to loess geohazards, drawing particular attention tothe need to apply research findings to recent, very large (mega-)construction projects in loess terrain such as the Mountain Excavation and City
\end{abstract}



creating $246 \mathrm{~km}^{2}$, and large engineered interventions in the landscape for gully control and land reclamation such as those in Shaanxi and Gansu generating agricultural land covering an area of some $8,000 \mathrm{~km}^{2}$. These projects are in response to increasing pressures to facilitate expansion of urban centres, their interconnecting infrastructures and their agricultural support systems. It is argued that,where proper application of scientific knowledge for engineering control (e.g. density, drainage)of these new landscapes is absent, these project generate a substantial, and costly geohazard legacy for future generations.

Keywords: Loess Plateau (China); loess geohazards; loess landslides; ground fissures; mega engineering projects. 


\section{Introduction}

Loess is an aeolian silt of engineering geological significance that has a global distribution; the earliest global distribution maps were produced by Alfred Scheidig in 1934 (Scheidig, 1934;Smalley, 1995) and an updated map was published by Trofimov et al. 2001 (in Trofimov et al., 2015). Prominent deposits are encountered in the plains of North America (e.g., Follmer, 1996), southern South America (e.g.,Zárate, 2003), the margins of the glaciated ice-age landscapes of north-western Europe (e.g., Haase et al., 2007), in Africa (e.g., Nouaouria et al., 2008; Assallay et al., 1997) and there are very substantial deposits across eastern Europe and into Asia (Jefferson et al., 2003; Liu, 1985). Smalley et al. (2001) provide a synopsis of early loess researchers.

The distribution of loess in China is particularly widespread with an estimated total cover of some $630,000 \mathrm{~km}^{2}$, comprising a nearly continuous cover of some $440,000 \mathrm{~km}^{2}$ forming the Chinese Loess Plateau and reaching maximum thicknesses greater than $300 \mathrm{~m}$ (Liu, 1985; Derbyshire, 2001; see Figure 1). Loess is a very fertile soil and has traditionally attracted many communities drawing the benefits of this unique material in China (Ho, 1969; Smalley and Smalley, 1983; Liu, 1985; Derbyshire, 2001). Rapid economic development and the concomitant expansion of urban footprints and connecting infrastructures has resulted in a significant increase in research into the geohazards posed by Chinese loess, illustrated by a rapid rise in publications since 2005 and an overwhelming proportion of the global scientific literature addressing loess geohazards in China (see Figure 2). 


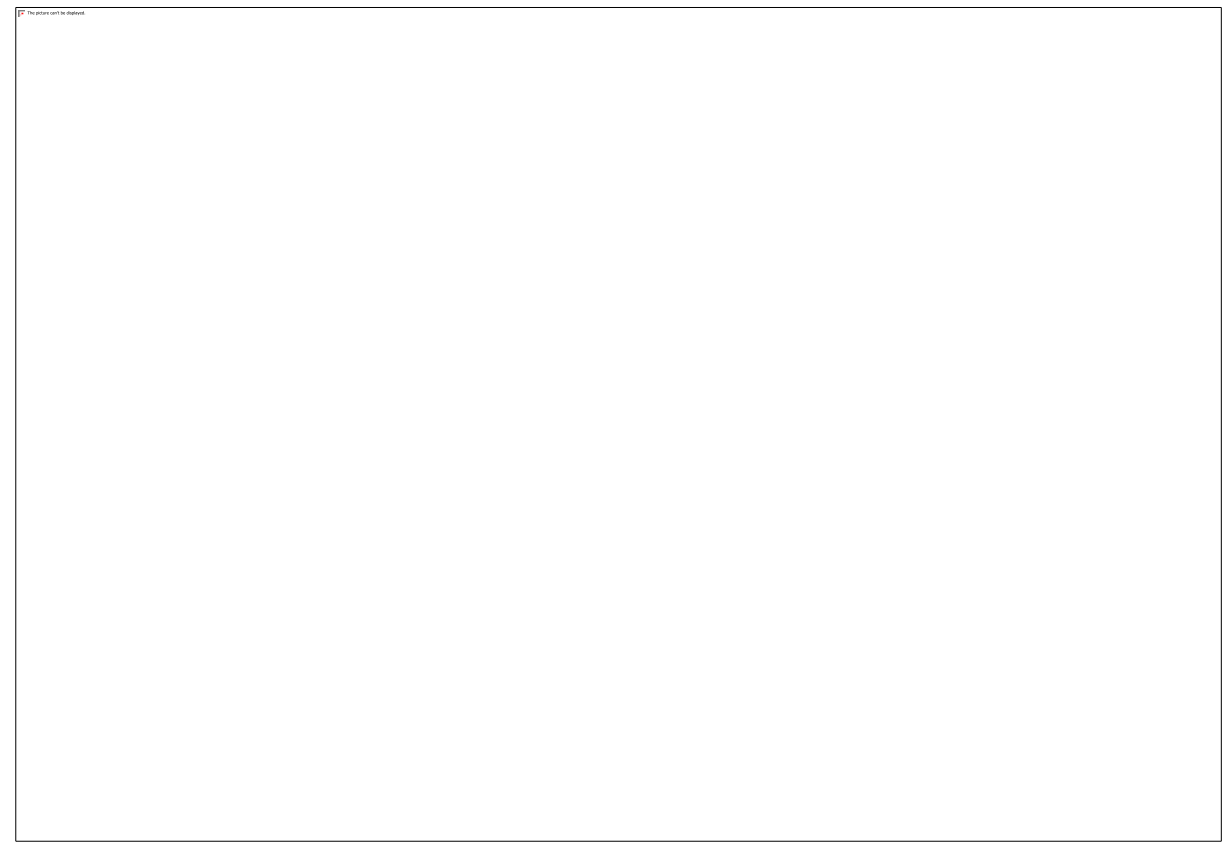

61 Figure 1. Loess distribution in Eurasia. The distribution of the European and Russian loess deposits is largely associated with the southern margins of the Eurasian ice sheets (simplified after Vasiljević, et al., 2014 and Svendsen et al., 2004). The Chinese loess is predominantly found to the east of the Tibetan Plateau (Liu, 1985).

It is evident that before 1995 very little research was reported in English literatures

onloess geohazards. Lutenegger (1988) edited a special issue of Engineering Geology

providing an early anthology of research into loess geotechnology and associated hazards, which included some early references to the special aspects of Chinese loess by Gao (1988) and Tan (1988). From the early 1990s, a European research consortium, in 
collaboration with researchers in Lanzhou, China, carried out research into the mechanisms of

72 large loess landslides in north-western China (Derbyshire et al., 1994; Dijkstra et al., 1994; Derbyshire et al., 2000).This work stimulated research into the meta-stable loess structure and its sensitivity to collapse upon wetting, which has severe implications for engineering performance and the stability of natural and engineered loess slopes and surfaces (for collections of early research on loess collapse and particle packing transformations see, for example, Rogers et al. 1995; Dijkstra et al. 1994; Derbyshire et al. 1995).

Figure 2. Google Scholar search returns show a surge in publications reporting on research into loess geohazards since the early 2000s. Nearly all these publications focus on China. 
both a macroscopic perspective (where heterogeneities such as palaeosols, extent of compaction and joint systems influence the formation of sinkholes, pipe systems and shear surfacesfor landslides) and a microscopic perspective (where the study of the characteristic porous nature and its transformations provide insights into the collapse mechanisms of loess (Gao, 1988). The meta-stable nature of this material makes the Loess Plateau one of China's physiographic regions that is most susceptible to geohazards (Derbyshire et al., 2000, 2001;

Xu et al., 2014).Approximately one-third ofall landslidesin China occur in this plateau and society's exposure to loess geohazards continues to increase with ongoing expansion of urban footprints and infrastructure (Zhuang et al., 2017; Peng etal., 2015, 2016a).

Loess geohazards significantly influencethe socio-economic development of the Loess Plateau; loess landslides continue to affect lives and livelihoods (Derbyshire et al. 2000) and major ground fissures such as those identified in the city of Xi' an affect construction and the development of pipelines and subways resulting in an economic impact estimated to exceed US\$1.6 billion (Peng 2012, Peng et al., 2008, 2013; 2016a). Furthermore, the presence of extensive networks of loess pipe systems and caves exacerbate issues of soil and water loss and have hindered the construction of transport infrastructure (such as high-speed railways) in the Loess Plateau (Peng et al., 2017b).

Dominant triggers of loess geohazards include rainfall, irrigation and construction. In this tectonically active region also earthquakes form a potentially catastrophic trigger 
mechanism; the 1920 Haiyuan earthquake triggered many thousands of landslides and resulted in large numbers of fatalities (estimates vary between 200,000 to more than 500,000; Close and McCormick, 1922;Dijkstra et al., 1995; Zhang and Wang, 2007; Wang et al., 2014; Zhuang et al., 2018b).

Large engineeringprojects in the Loess Plateau include the construction of a New District of Lanzhou (LZND) in Gansu Province (see Figure 3; Pacific Construction Group Company, 2014). Elsewhere in the Loess Plateau, projects of similar dimension are being carried out, including the 'Mountain Excavation and City Construction' for urban expansion in Yan'an, Shaanxi and the very large landscaping projects for agriculture such as the 'Gully Stabilization and Land Reclamation' and the 'Gully Control and Highland Protection' projects in Shaanxi and Gansu(Ministry of Natural Resources, PROC, 2012). These projects result in major engineered interventions that significantly alter the loess landscape and will require the full application of the state-of-the-art of loess research to minimize the potentially negative implications of these interventions that future generations may have to deal with (Dijkstra et al. 2014; Li et al., 2014). 


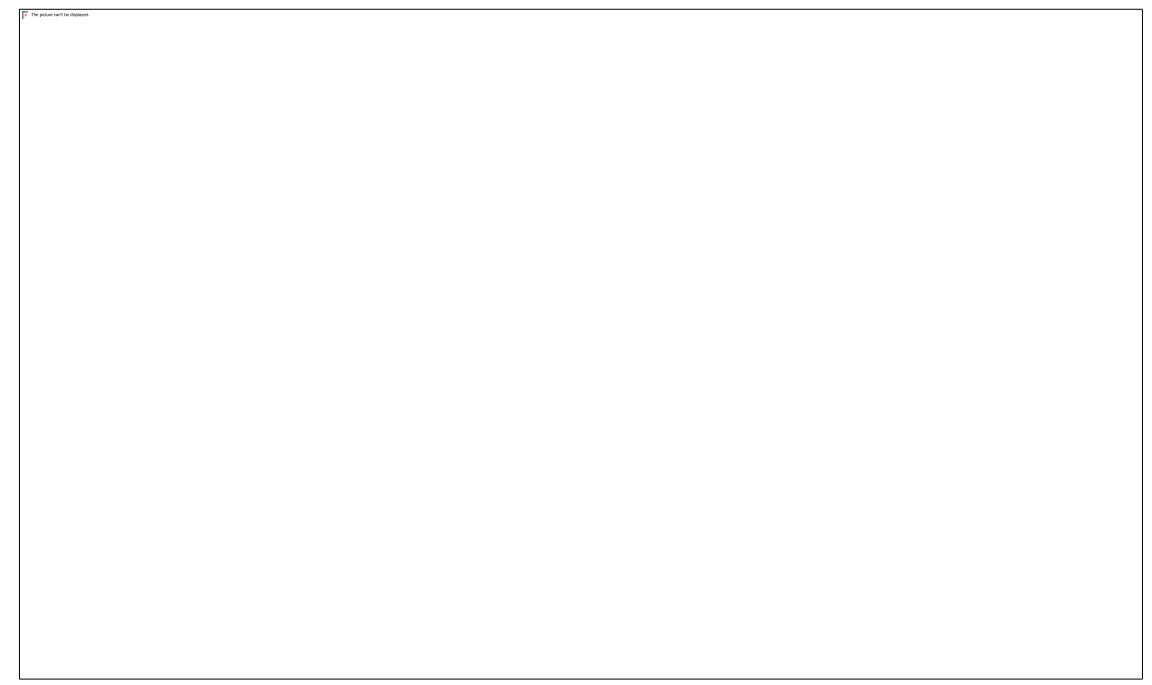

Figure 3. An example of the magnitude of landscape alteration to accommodate urban expansion of north-eastern Lanzhou at Qinbaishi (Photo: Dijkstra).

This paper focuses on the advances in the field of loess geohazard assessment and mitigation in China and discusses the potential challenges and the research needs in the context of ongoing very large land-creation projects in the Chinese Loess Plateau.

\section{Characteristics of loess in China}

The Chinese Loess Plateau is a more or less continuous drape of aeolian silts of substantial thickness (from around $5 \mathrm{~m}$ to more than $300 \mathrm{~m}$ ) that have been deposited during the past twomillion years (Liu, 1985). Although the particle size distribution represents a 
uniform material (predominantly $<60 \mu$ ), there are important regional variations in both claysized fraction and clay mineral content that result in the need for a regionally specific geotechnical characterization of loess (Derbyshire et al., 2000). As a consequence of the aeolian deposition and subsequent weathering, slightly coarser loess ('sandy' loess) is found in the northwestern parts of the Plateau with a gradual increase in the proportion of smaller grain sizes and also clay mineral content towards the southeast.

Loess structure is characterized by an open packing where cementation bonds maintain a meta-stable fabric dominated by silt particles and supported by bridges consisted of clay-sized particles, such as calcite and clay minerals (Dijkstra et al., 1995). When cementation bonds fail (in shear or as a consequence of wetting up)this open fabric collapses resulting in potentially rapid packing transformations and an equally rapid loss of shear strength. The degree of collapsibility of the fabric strongly depends on depositional environment and stress history (age); this has resulted in intensive research efforts focusing on linking micro-structure to the mechanical behavior of loess (Derbyshire and Mellors, 1988; Fredlund and Rahardjo, 1993; Hu et al, 2001; Zhang et al, 2013b; Jiang et al., 2014; Xu et al., 2017 \&2018; Liang et al. 2018; Luo et al., 2018; Zhang and Wang, 2018). Recent developments are making good use of enhanced resolution of computed tomographyscanning and advanced image processing techniques to investigate 3D changes in loess microstructure (Zhao et al. 2017). 
The loess landscape is very dynamic and heavily influenced by tectonics leading to the development of joint systems that, in turn, influence loess slope morphologies and the position and timingof loess geohazards. Extensive field surveys of loess slopes coupled with a statistical analysis of joints and fissures and the mapping of weak interfaces (such as paleosols) enabled the establishment of a relationship between the internal loess slope structure and landslide occurrence (Derbyshire et al., 2000; Wang, et al., 2011; Peng et al., 2016a, 2016b, \& 2017b, 2017d; Zhuang et al., 2018).

\section{Loess Geohazards Research in China}

\subsection{Loess landslides}

\subsubsection{Classification and distribution}

In the 1970's, the Chinese Department of Railway Construction categorized loess landslidesin terms of the main mode of loess deposition/reworking; alluvial, eolian, and colluvial. A further set of sub-categories were identified to represent depth to slip surface; shallow, intermediate-depth, and deep (Chinese Academy of Sciences, 1975). In turn, different types of loess landslidescould be distinguished based on the location of the slip surface; 1) slip surfaces within a single loess layer; 2) slip surfaces located at the interface between the different loess layers; 3) slip surfaces located at the interface between loess and underlying bedrock with bedrock strata dipping inthe same direction as the slope; and 4) slip 
surfaces located at the interface between loess and underlying bedrockwith bedrock strata dipping into the slope. These classes are widely reported in engineering practice in China. The special nature slope movements in loess was highlighted inVarnes' 1978 classification who created a special category for dry (seismically-induced) flows in loess. This feature was updated inHungr et al. (2014)who describe the phenomenon of loess flowslides in detail. The three most significanttypes of movement in loess slopes that areusedChina includeflows, slides and slope collapses (Xu et al., 2011).

\subsubsection{Triggering and kinematic behavior}

Loess is very sensitive to water and loses strength rapidly uponwetting. There is extensive evidence that precipitation and irrigation lead to slope failure(Zhang et al., 2017; Xu et al., 2012b; Leng et al., 2018; Qi et al., 2018; Luo et al., 2018). Research has shown that loess shear strength is dependent upon variations in moisture content with a complete loss of cemented strength and a reduction in frictional resistance as the material wets up (e.g. Derbyshire et al., 1994, 2000; Zhang et al., 2013b; Peng et al. 2017c,2018a). Rainfall simulations indicated that the depth of water infiltration in the loess slopes was generally less than $4.0 \mathrm{~m}$ (Tu et al., 2009; Zhuang et al., 2017; Wang et al., 2018). However,a field tests (such as rainfall simulations and in-situ permeability tests, sometimes coupled with geophysical surveys) and laboratory tests have shown that water can infiltrate deep into the thick loess through networks of microscopic pores leading to a loss of strength and high transienthydrodynamic pressures within the joints and fissure networks (Derbyshire et al., 
2000;Xu et al., 2012a; Zeng et al., 2016; Zhuang and Peng, 2014b; Zhuang et al., 2017; Peng et al., 2017c, 2017d, \& 2018a)).

Increasingly, loess table-landscapes (tai in Chinese) are being irrigated to enable agriculture and afforestation. Particularly, in the semi-arid to arid western margins of the Loess Plateau this can lead to large settlements as the open, meta-stable loess fabric collapses. Rising groundwater levelsin loess tablelandslead to widespread instability along their margins. The Heifangtai Yellow River terrace (approximately 60km west of Lanzhou, Gansu) is a natural laboratory for the study of loess geohazards and recent research there has generated significant insights into the mechanical behavior of loess and the initiation of fastmoving flowslides in loess (Zhang et al., 2013a; Peng et al. 2017d; Qi et al., 2018; Xu et al., 2012a; Zheng et al., 2016; Zhang and Wang 2018; see Figure 4). 


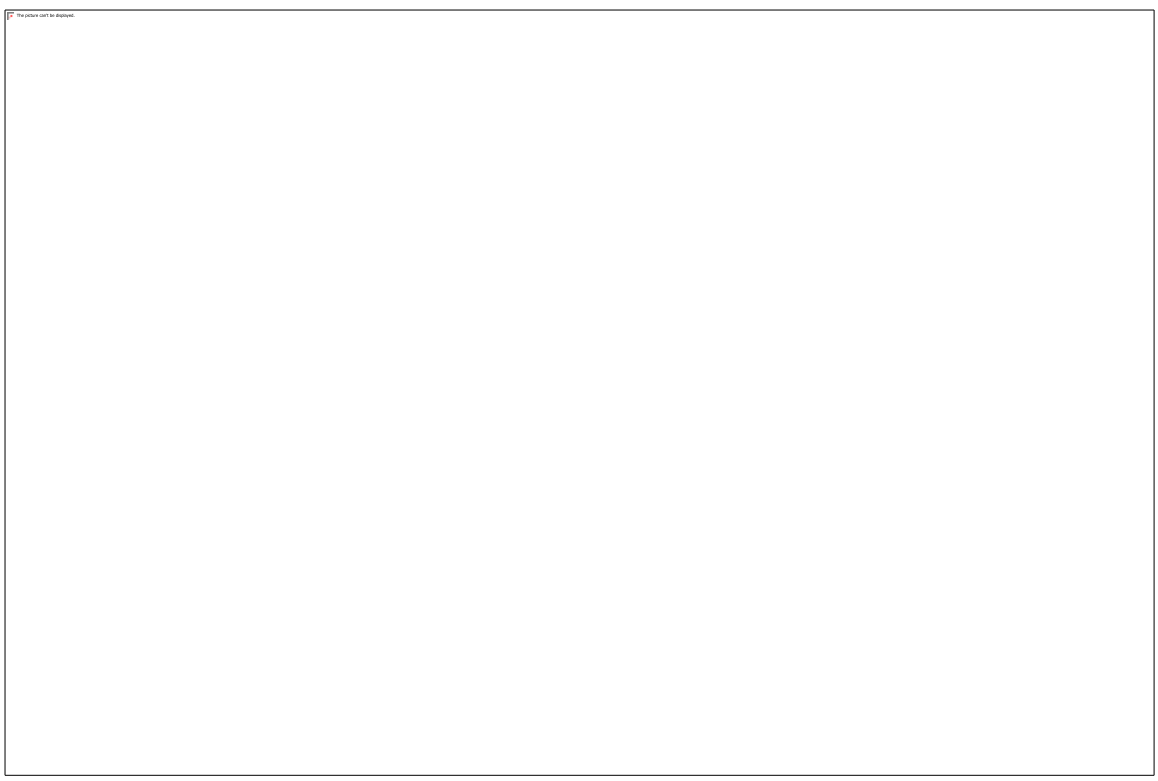

Figure 4. The site of the loess flow-slides in 2015 that affected the village of Dangchuan (slide DC2 in Peng, et al., 2016). This photo was taken in September 2018 and shows that the slide margins are still adjusting and that the centre of the basin is perpetually wet due to groundwater seepage (Photo: Dijkstra).

The mechanisms behind the phenomena of loess landslides and their evolution from slide to flow, with the catastrophic consequences of high-speed, long-runouts have been the subject of extensive studies. Both field and laboratory tests showed that thesehigh-speed and long-runout loess landslides were the outcome of the liquefaction of the loess (Zhang et al., 2017; Picarelli, 2010; Xu et al., 2012a; Peng et al., 2018a,b). The collapse of the loess structure caused by the shearing failure of saturated or partially saturated loess is known to result in a sharp increase in the pore water pressure and a rapid decrease in the shear strength, 
in which the loess behaves as a fluid (Peng et al., 2018a \& 2018b; Zhang and Wang, 2007). Further, Peng et al. (2018a) observedthat liquefaction of both loess and underlying alluvial sand significantly amplified the speed and runout distance of loess flows/flowslides.

\subsubsection{Monitoring and early warning}

The monitoring of loess landslides and the development of early warning systems has been the subject of extensive studies (e.g., Zhuang et al., 2014a, 2018a). Based on their focus and the explored investigation techniques, these studies may be categorized into three groups: regional rainfall data analysis, surface displacement monitoring and remote sensing applications.

The analyses of long-term regional rainfall data and loess landslide occurrence has resulted in statistical analyses aimed at establishing empirical loess landslide trigger thresholds. For example, Zhuang et al. (2014a) analysed three decades of loess landslide and rainfall data and managed to establish a loess slope failure early warningsystem forXi'an.Otherregional rainfall thresholds for loess landslidetriggering are reported by Chen and Wang (2014), Zhuang and Peng (2014b) and Zhuang et al. (2018b).

Surface displacement data have been used by Wang (1997) to forecastthe time of occurrence of two landslide events on the Heifangtai Yellow River terrace(reported in Zheng, 2017; Peng, D.L. et al., 2018).However, this type of monitoring, often coupled with intensive 
in-situslope instrumentation,istypically expensive and is limited to applications where particularly high-risk, potential landslide events have been identified.

Remote sensing techniques and advanced 3D imaging technologies have been usefullyexploitedto investigatethe spatial and temporaldistribution of unstable slopes. Specifically, drones have recently been used for the 3D topographic mapping at different timescalesto inform landslide deformation calculations (Eltner et al., 2015; Hu et al., 2017). With the current centimetric precision of drone imaging technology (Wasowski and Bovenga, 2015), these 3D aerial monitoring techniques have been regularly used for regional scale landslideassessment and forewarning in river basins (e.g., Hu et al., 2017). Space-borne synthetic aperture radar interferometry (InSAR) technology has been increasingly used for regional and local scale assessment and monitoring of landslides (e.g., Colesanti and Wasowski, 2006; Wasowski and Bovenga, 2014, 2015;Wasowski etal., 2014; Zhang, Y. et al., 2018). However,thusfar InSARhas been rarely employed in the investigations of loess landslides in the Loess Plateau (e.g., Wasowski et al., 2012; Zeng et al., 2014). Small prefailure strains in relatively brittle loess deposits coupled with topographic complexities limit the opportunities for the early detection of potential loess landslides. Nevertheless, some InSAR-based analyses have provedsuccessful in monitoring potential landslide sites in both South Jingyang and Heifangtai tablelands(; Liu, 2015?;; Zhao et al., 2016; Xue et al., 2016).

Furthermore, Qi et al. (2018) used InSAR to reconstruct retrogressive loess landslide events at 
Heifangtai. There is therefore scope for further application of this technique to analyse spatial and temporal patterns in loess (slope) deformation.

Despite the above advances it is clear that theearly detection of loess landslide initiation across the Loess Plateau remains elusive. Empirical approaches have delivered some success, but their widespread application is limited. This is largely the result of a relative lack of appropriate slope stability models that can be used to analyse the process-response system of hydrologically-triggered loess landslides. The most promisingapproachwould therefore appear to develop more comprehensive slope deformation process modelsthat can be tested against comprehensive monitoring data setsderived from an integration of remote and in-situ based techniques.

\subsubsection{Mitigation and control of loess landslides}

Loess landslides are triggered by a variety of factors and local environmental conditions result in a complex, and often poorly understood variation in landslide susceptibility. The characterization of the engineering geology of loess slopes therefore still requires substantial further research effort. Where potential loess slope deformations carry significant risk to lives and livelihoods, engineered interventions and ecological control mechanisms have been implemented providing examples of good practice that can be applied elsewhere to manage the slopes and mitigate the potential impact. For example, Meng et al. (1991) used a combination of shear piles and retaining structures to stabilize and control loess 
landslides in urban districts of Tianshui (Gansu Province). Jia (2016) outlines the design of retaining walls tomaintain loess slope stability. The design of engineered interventions to stabilize loess slopes needs to carefully consider the role of water. For example, Dijkstra (1994) evaluated the gradual deterioration of slope stability using a caste study of infiltrating waste-water on a 9m high loess cutslope in Lanzhou;Liu (2015) proposed a stabilization scheme of loess slopesthat includes representation of hydro-geological processes; andChen et al. (2017) used experimental work, a limit equilibrium analysis and a numerical simulation to developa method for evaluating the stability of loess slopesas it is affected by infiltrating water.

Ecologicalinterventions have had some success in protection loess slopes (Wang et al.,2003) with large scale experiments providing new data on the friction of the interfaces between roots and soil, and the ways in which root systems provide additional stability for loess slopes. This research culminated in the design of vegetation root mats for slope protection (Wang et al., 2010). However, it must be noted that these techniques can provide additional resistances for relatively small slope volumes. Loess landslides rapidly attain a size where vegetation becomes a passenger in the slope deformation process. Additionally, much further research is required to evaluate the consequences of afforestation of loess slopes in semi-arid environments. The irrigation water required to sustain the afforestation process can result in detrimental consequences for loess slope stability, manifested in the form of erosion, soil piping, extensive fabric collapse and loess landslides. 


\subsection{Ground fissures affecting loess}

\subsubsection{Origin of ground fissures}

Peng et al. (2007)foundthat the presence of fractured rock mass generated by tectonic activity was a significant factor leading to deep-seated loess-mudstone deformations in the Fen-Wei basin. This finding was supported by the works of Wang et al. (2014) and Shi et al. (2016)..The Fen-Wei Basin, located in the southern and eastern part of the Loess Plateau, is known for a remarkable latticework of ground fissures, with more than 430 fissures detected since the 1950s. These fissures have caused extensive damage to construction and infrastructure, resulting in significant financial loss (Peng, 2007; Peng, 2017d). Some 14 large ground fissures in the city of Xi'an threaten both the urban infrastructure and public safety.

Over the past 30 years, the spatial and temporal distributions, failure patterns, and formation mechanisms of theseground fissures havebeen studied usinggeological and geophysical surveys, physical simulations, remote sensing, GPS monitoring and numerical analysis (e.g., Peng, 2012; Peng et al., 2013). The Fen-Wei Basin has been undergoing an elongation in the NW-SE direction with a velocity of 2-5 mm/year, which can be attributed to the eastward extrusion of the Qinghai-Tibet Block and the uplifting of the Ordos Block(Peng, 2012; Peng et al., 2013). Collapse of the loess fabric due to over-exploitation of groundwater further contributes to surface deformation and therefore most hypotheses appear to agree that a combination of these factors (hydro-geological and tectonics) constitute the most important causes for the formation and ongoing deformation of these fissures (Peng, 2012;Peng et al., 
2007; 2016c).The consequences for urban developmentare severe with an increasing number of buildings and connecting infrastructure, including metro-lines, at risk from continuousdisplacements along these fissures (Peng et al., 2017a; see Figure 5).
Commented [TD4]: this can be deleted.

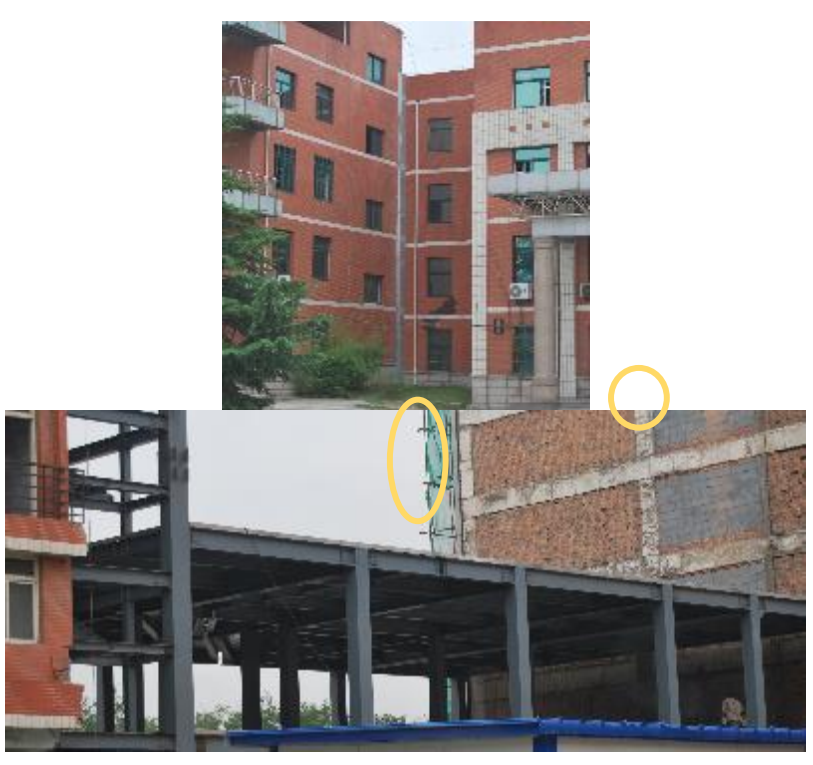

Figure 5. Damage to a University building in Xi'an where a ground fissure has caused relative displacement along the connection between two buildings (left) and (right) construction of a new building across an active fissure. To accommodate relative movement, the floor slabs are separated by a small gap: an imaginative solution, but of questionable sustainability (gap in floor slab is visible in yellow circles. (Photos: Dijkstra). 


\subsubsection{Mitigation and control of ground fissures}

China'seconomic development has resulted inrapid urban expansion and a need toextend large-scale infrastructure networks (both above and below ground surface) in the Loess Plateau. The safety of the infrastructure spanning ground fissures has become a significant concern for urban planners and hazard managers (Peng et al., 2013).In particular, new methods were required to design appropriate prevention and control methods to ensure the integrity of the metro tunnels where these cross ground fissures(Wu et al.,2005;Liu and Liu, 2017)). Large-scale physical experiments enabled simulation ofeffects of these fissures on thedeformation and failure limit states ofa range of structures and metro tunnels and the development of appropriate design codes, ground improvement schemes and safe offset distances between buildings and fissures (Peng et al., 2013, 2016c, 2016e, 2017a).

\section{Loess Geohazards Research Challenges in China}

With the implementation of the Western Development Policy and the Belt and Road Policy by the Chinese Government, severalmega construction projects have been undertaken in the Loess Plateau. Theseincludetwo mega projects for urban expansion; theMountain Excavation and City Construction (MECC) and the Lanzhou New District (LZND) projects; and two large scale landscaping project for mainly agriculture; the Gully Stabilization and Land Reclamation (GSLR) and the Gully Control and Highland Protection (GCHP) projects. These projects are associated with the recent local Government policy for "land creation" to 
meet the need for the rapid economy growth in China, but there is a risk of a concomitant rise in loess-related geohazardswhere these projects are implemented without carefully designedengineering controls(e.g. density, drainage, volume stability; Dijkstra et al., 2014; Li et al., 2014; Peng et al., 2014, 2016b,c). To gain a better insight into the potential geohazards that might result fromthese ongoing large-scale engineering activities in the Loess Plateau, there is a need to build on existing research foundations and further carefully investigate: (1) howchanges in loess structure (from undisturbed toreworked/remoulded)influences failure behavior; (2) howinteractions between water and loess in these new landscapes can give rise to excessive volume changes (piping, subsidence, collapse, hydro-consolidation) and potentially catastrophic loess landslides; (3) how potential future seismic activity affects loess deformation (e.g. fabric collapse of level surfaces, or catastrophic slope failure in natural and engineered slopes); (4) what tools can be developed to better forecast loess geohazards;

(5)what opportunities can be mobilized to mitigate the impact of loess geohazards and achieve sustainable socio-economic development across the Loess Plateau. These challenges are discussed in detail below with reference to the mega-projects being undertaken in the Loess Plateau.

\subsection{Major landscaping to accommodate urban expansion}

In the undulating topographies of the Loess Plateau, rapid urban development and population growth result in tremendous shortages of suitable space for construction. This section illustrates two projects where new land is created through the "removing the tops of 
mountains to fill in valleys" for urban development (Dijkstra et al., 2014; Li et al., 2014). In Yan'an City, Shaanxi Province, the Mountain Excavation and City Construction (MECC) project is underway to expand the areas of flat land and create a New District. The project started in 2012 and is expected to be completed by 2022. In Lanzhou city, Gansu Province, a similar New District (LZND) is being created that will ultimately cover some $246 \mathrm{~km}^{2}$ of new level ground for construction.

\subsubsection{Mountain Excavation and City Construction (MECC): Yan'an, Shaanxi}

The conservation of physical space in the Loess Plateauis of extreme importance. In Yan'an City, Shaanxi Province, approximately 500,000 people live within an area of only 36 $\mathrm{km}^{2}$. To cope with the overcrowding problemin this famous historic city, the Mountain Excavation and City Construction (MECC) project, a flat land creation effort, has been undertaken to create a New District. The MECC project, that started in 2012 and is expected to be completed by 2022, shouldcreate new land for urban development by "removing the tops of mountains to fill in valleys" (Li et al., 2014). The project'saim is the creation of approximately $78 \mathrm{~km}^{2}$ of flat ground with an estimated cost of US\$10 billion. Although the large-scale implementation of the MECC project can provide more land for urban development (see Figure 6 for the recent land use and topography change in the New District of Yan'an City), this will also inevitablylead to an alteration of the local geological environment. 


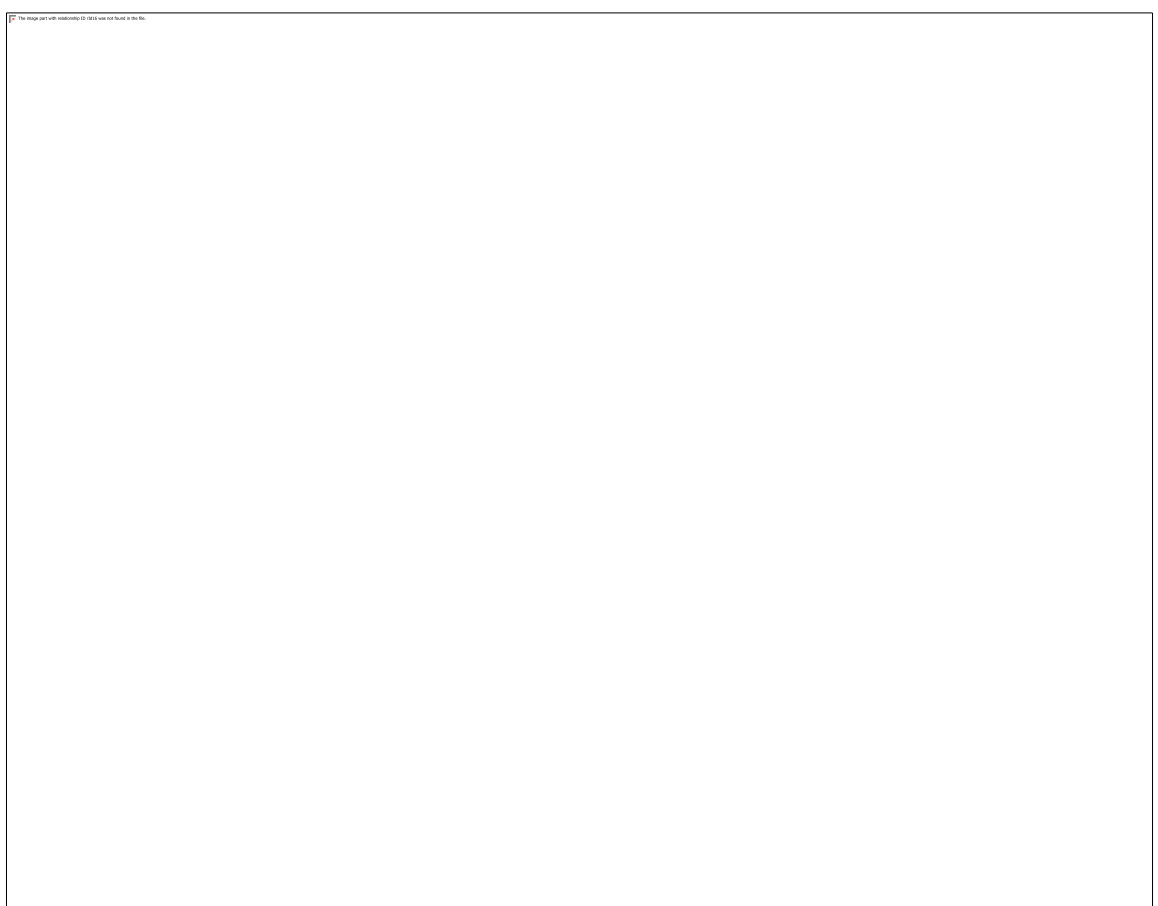

Figure 6. FourGoogleEarth ${ }^{\mathrm{TM}}$ imagesof the New City District in Yan'an City illustrating a rapid land use and topography change in the period 2012-2016(https://earth.google.com/web/)

\section{It is apparent that the project requiresa meticulous scientific assessment of}

potentialnegative environmental consequences. There appears to be an absence of scientific

studies needed to collect geotechnical and geological data for the optimal design and

construction of the excavation may lead to new loess geohazards, such as the failure of man-

made loess slopes and the post-constructionsettlement of loess fill foundations. Ground
Commented [TD6]: Xingmin/Hsein, is there any information on environmental impact assessments having been carried out before these projects commenced? I am not aware of any. 
settlement in the loess fill area and slope deformation in the mountain excavation area in the New District in Yan'an City are widespread and substantial (Figure 7). Furthermore, largescale loess fill, which is known to influence both the surface water infiltration and the groundwater migration in that region, may in turn negatively affect the local environment needed for hosting water resources. The difficulties inherent in the MECC project could be summarized as follows: 1) lack of scientific data on the failure modes of the loess fill foundation, in terms of the key influencing factors, 2) absence of models for determining the deformation and collapse behavior of the loess fill foundation, 3) possible coupled deformation of the loess-water system, and the mechanisms of new loess geohazards from this project, and 4) an apparent absence of consideration of the environmental impact of this scheme in both the short and long-term.

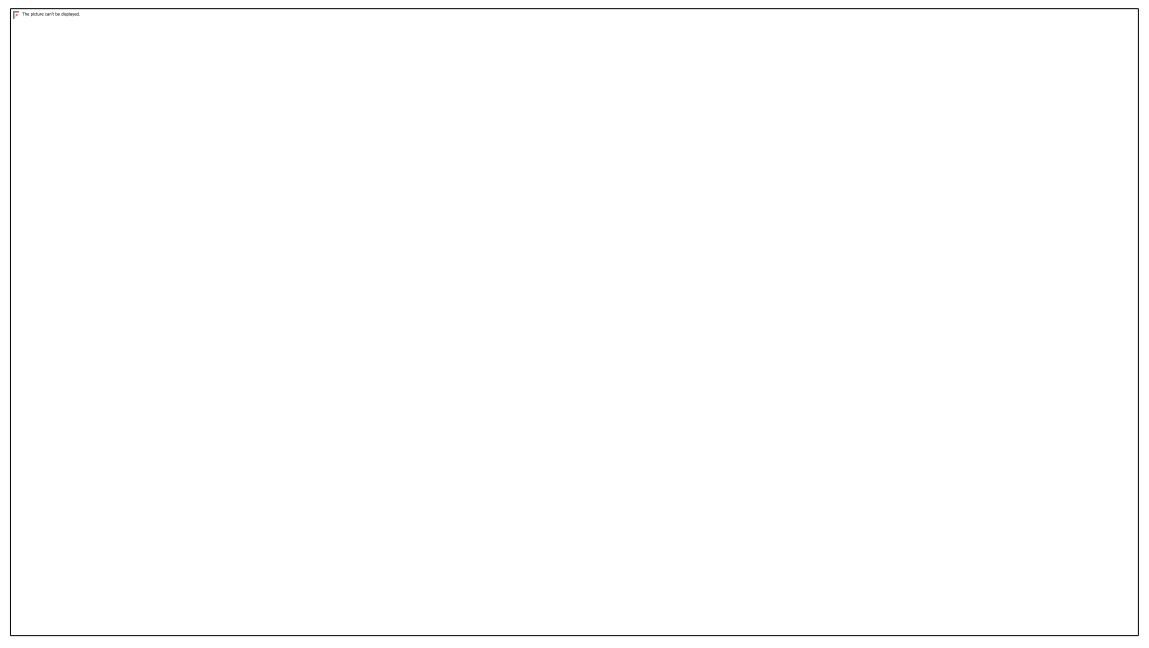


Figure 7. InSAR results revealingthe ground settlement in the loess fill area and the slope deformation in the mountain excavation area in Yan'an City (Jianbing Peng, personal communication)

\subsubsection{Lanzhou Qingbaishi and Lanzhou New District (LZND)}

The northern fringe of East-Lanzhou at Qingbaishi consists of a hilly topography with a relative relief of more than $100 \mathrm{~m}$. The local bedrock consists of a sequence of Neogene-age mudstones and sandstones; the bedrock is overlain by river sands, gravels and alluvial silts (deposits of the Yellow Riverpalaeo-terrace), on top of which aeolian loess deposits are found with a maximum thickness exceeding $100 \mathrm{~m}$. As part of a 20 billion RMB (approximately US\$3 billion) development project, some 700 loess hills are being 'reclaimed' in the Qinbaishi District (Figure 3, 8). The Lanzhou New District (LZND) is the state-level new district approved by the Chinese Government State Council in August 2012, and represents the first and the largest national-level "new area" in the Loess Plateau region.The scope planning covers sixtowns in Yongdeng and Gaolan counties of Lanzhou City, covering a total area of $1744 \mathrm{~km}^{2}$, with a planned ultimate construction area of $246 \mathrm{~km}^{2}$ and a project population of nearly 300,000 people.

InSAR-derived vertical velocity maps have been constructed to better understand the terrain instabilitycaused by these large-scale construction activities in in the Qinbaishi District.The resultshighlight pockets of downward vertical movement between 15 and $55 \mathrm{~mm}$ per year (Figure 9; Chen et al., 2018).
Commented [U7]: I gather that this is a 22 day interferogram, but it would be good to know the radar imagery used and to have the color scale to explain the amount of the detected ground surface displacements 
hydrogeological controls, drainage, and suitable preparation (e.g vegetation removal) of the

landscape on top of which new loess is end-dumped. Further, there is only limited evidence of density control of the valley fills, mainly through dynamic compaction. The absence of adequate scientific studies to collect geotechnical and geological data for design and construction of buildings and infrastructures may lead to negative consequences, including geohazards and man-made disasters in the Loess Plateau.

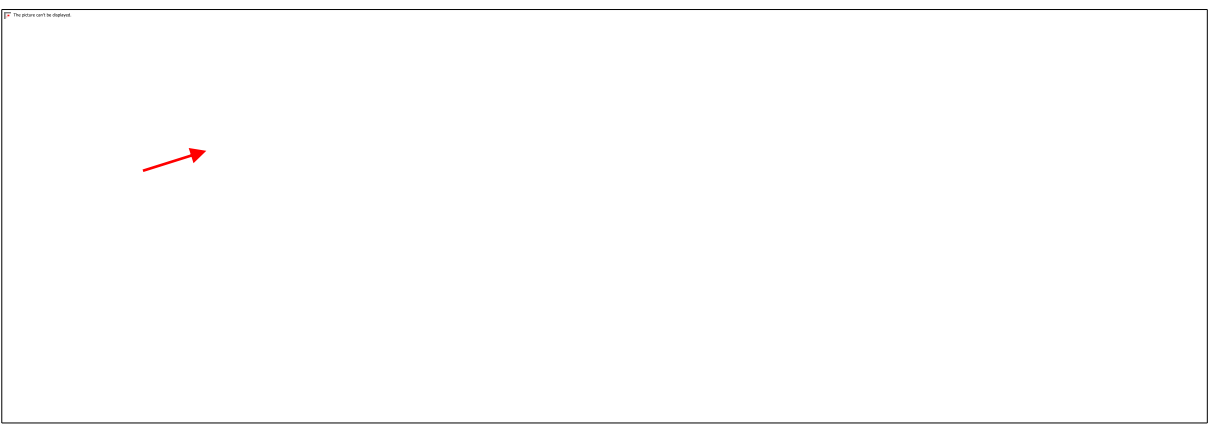

Figure 8. Landscape modifications at Qingbaishi, Lanzhou. The landscape in 2011 shows an undulating loess topography with elevations ranging from approximately 1600 to more than $1750 \mathrm{~m}$. The 2018 landscape shows ongoing valley filling and extensive construction on newly formed surfaces. The western settlement presently shows signs of widespread subsidence affecting roads and services (the direction of the photo of Figure 3 is indicated by a red arrow). Images courtesy Google Earth ${ }^{\mathrm{TM}}$.
Commented [U9]: not clear to me

Commented [U10]: this has already been said above when discussing the MECC project 


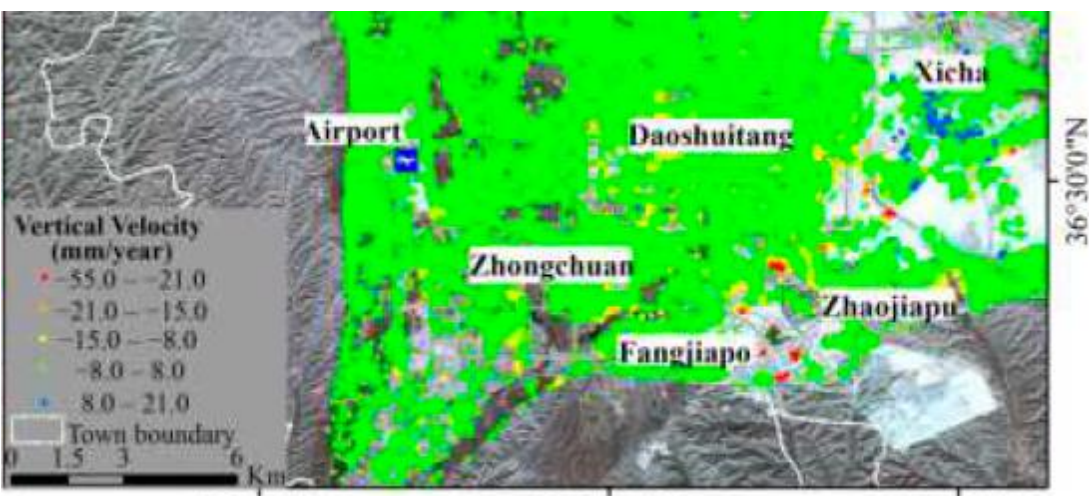

$103^{\circ} 3^{\circ} 0^{\prime \prime} \mathrm{E}$ $103^{\circ} 400^{\prime \prime} \mathrm{E}$

Figure 9. Detail of the InSAR-derived average annual vertical displacement velocity mapsover the LZND(Sentinel-1A for 2015-2016 using the SBAS technique(after Chen et al., 2018).

\subsection{Gully Stabilization and Land Reclamation (GSLR): Yan'an, Shaanxi}

A substantial part of the Loess Plateaucomprises a highly fragmented topography oflevel surfaces intersected by steep-sided gullies (Figure 10). comprises is reflected by widely distributed gullies, offers scarce agricultural land resources. The 5-year Gully Stabilization and Land Reclamation (GSLR) project in Yan'an City, Shaanxi Province, was aimed at: 1) increasing agricultural land resources; and 2) reducing water and soil loss through sustainable and modernized agricultural management in the Loess Plateau. The GSLR project created approximately $360 \mathrm{~km}^{2}$ of agriculture land with a cost of US\$4.83 billon.

Commented [U11]: unclear to me

Commented [U12]: not in References; also, a better quality figure or copy of the paper would be needed to understand Figure 9

Commented [TD13]: use detail of the figure to get away from copyright issues. Will still need better quality figure. 


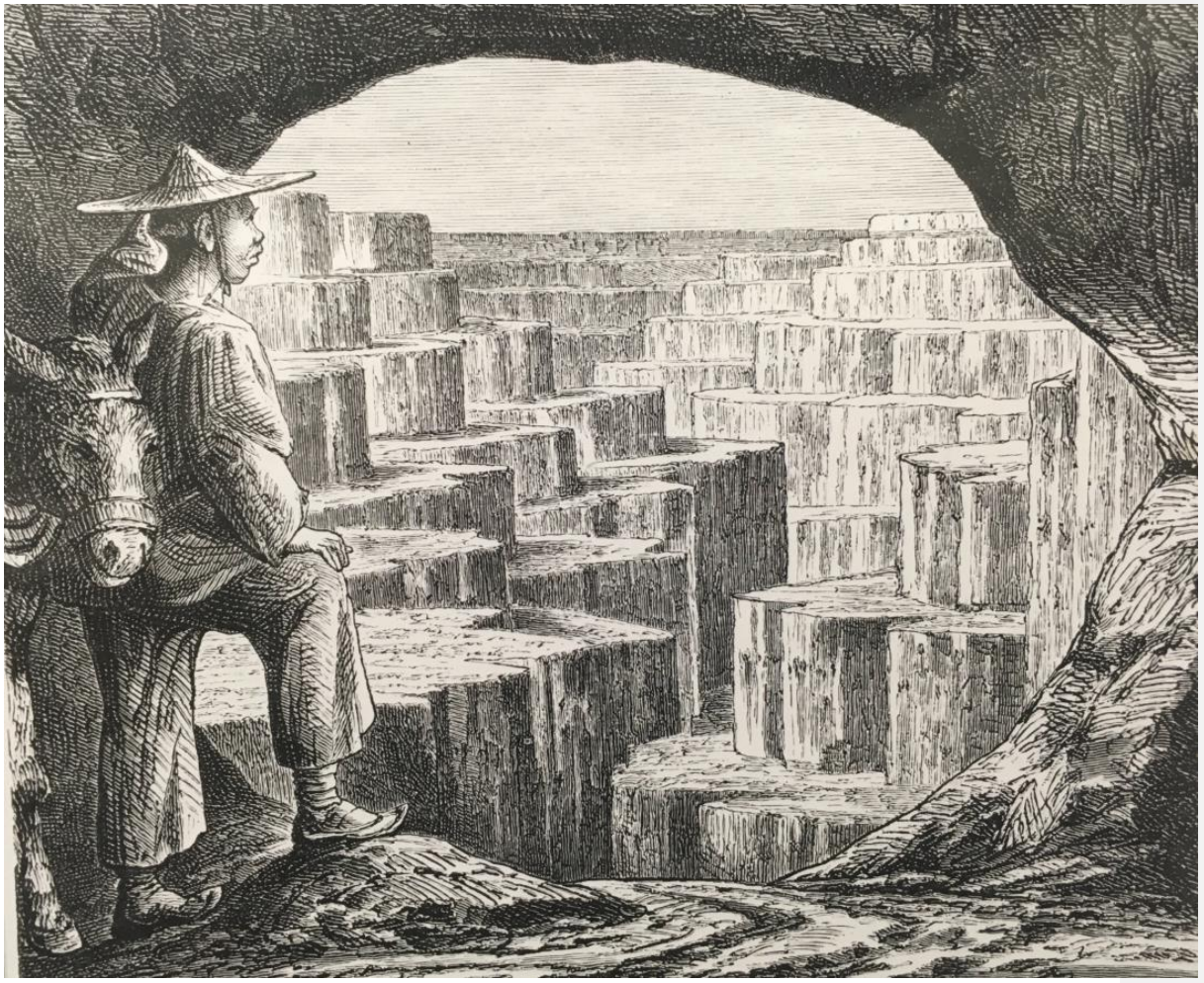

Figure 10. An engraving from von Richthofen (1877) showing an overview of a terraced loess terrain with steep-sided gullies in Shanxi.

The large-scale implementation of the GSLR project could significantly change the hydrological ecosystem of the valley and thus induce new natural and environmental disasters, such as the failure of silt dams, flood and mudflow hazards, instability of loess slopes, water accumulation, land salinization, soil erosion, and ground collapse in farmland. However, the mechanisms of the loess slopeinstability induced by the GSLR project remain unclear; the theoretical framework for evaluating the stability of loess slopes in these settings
Commented [TD14]: I know this is a bit indulgent, but I couldn't resist. It's a classic work that needs recognition. It was the earliest description of Chinese loess landscapes that reached an audience in the West...). 
remains unestablished; there is an absence in modelling capabilities tocarefully evaluate the dynamic nature of these landscapes and the evolution of slope instability; the time-dependent deformation behavior of loess slopes following the implementation of the GSLR project has not been systematically studied; and as for the other examples discussed in this paper there remain uncertainties in the quantification of interactions of loess and water, and the potential consequences for widespread and potentially catastrophic failures. All these issues warrant further research and, more important, implementation of research findings in design and management of these ongoing mega-projects in the Loess Plateau.

\subsection{Gully control and Highlandprotection}

Urban development and agricultural activities have greatly increased the incidents of gully and soil erosion in the Loess Plateau; these events gradually extend towards the center of thehighlands that make up the Loess Plateau. For example, soil erosion is a problem across theDongzhiyuanHighland(the largest highland in the Loess Plateau) and thisresults in the deposition of nearly 66 million tons of silt into the Yellow River per annum. Progressive gully erosion is a significant feature ofthe Dongzhiyuan Highland(Figure 11); the width of this Highland has decreased from $32.0 \mathrm{~km}$ in the Tang Dynasty (about $1200 \mathrm{yrs}$ BP) to $17.5 \mathrm{~km}$ at present. The Gully Control and Highland Protection (GCHP) project is being undertaken to mitigate and control further gully and soil erosion in this region. The GCHP project mainly covers the area of Qingyang in Gansu Provinceand is expected to create approximately 7,357 
$\mathrm{km}^{2}$ of land resource during the periodof 2013-2030, with an estimated total costof US\$8.43 billon.

8

0

2
Figure 11. Gully erosion in the Dongzhiyuan Highland in the Loess Plateau (Image courtesy Google Earth $\left.{ }^{\mathrm{TM}}\right)$.

For a project of such large dimensions, the design and implementation should be based upon rigorous scientific study of gully erosion characteristics to avoid the potential negative consequences of the human activities and unforeseen ecological problems (e.g., as alerted by Li et al., 2014). In light of the ever-increasing gully erosion and soil erosion caused by largescale urban development and agricultural activities, it is essential to investigate the interaction between loess erosion processes and gully stabilization in the Loess Plateau. A systematic 
study needs to be undertaken to investigate: 1 ) the migration of surface water in the loess gully area, 2) the interaction between water infiltration and internal structure of loess, and 3) the mechanism of the seepage erosion in loess. With regards to the Dongzhiyuan Highland, this data can then be used to 1) derive the mechanisms and modes of loess gully erosion and soil erosion under the influence of human activities, and 2) advance the new gully stabilization and highland protection techniques and standards. The study results may also provide scientific support for the sustainable development of both land resources and urbanization in the Loess Plateau.

The Loess Plateau is a region of strategic significance to China given the presence of many energy production facilities (i.e. involving oil, gas, and coal) as well as substantial agricultural assets. The implementation of the Belt and Road Policy by the Chinese Government can only increase the scale of the existing infrastructures there, particularly in terms of new highways, high-speed railways, and urban transit corridors and airports. Although the large-scale infrastructure construction projects may well provide unprecedented opportunities in the Loess Plateau, the possible byproducts of multiple loess geohazards and associated risks for society pose great challenges to the engineering communities. Therefore, not only is it imperative to drive forward a research agenda that builds on our current understanding of loess geohazards, including slope instability, subsidence and erosion, but it is also essential that our current understanding of key properties and processes of loess 
isimplemented in the design and management of loess landscapes, both natural and engineered.

\section{Concluding Remarks}

Research into theengineering geology and geomorphology of the Chinese Loess

Plateau has yielded a comprehensive foundation of knowledge regarding geohazards in this unique region. This research has provided new understandingof, among many others,microand macro-structural behavior of loess and the triggering and post-failure behavior of loess landslides. Furthermore, monitoring and modellingof ground deformations in the vicinity of loess fissures has provided insights into sustainable construction on and in ground affected by these discontinuities. Various teams continue to work on furthering our knowledge of loess geohazards. With the continued, and accelerating, modifications of loess landscapes through the mega-projects illustrated in this paper, it is imperative that this research continues to push the frontiers of knowledge. Engineering geologists have a key role to play in underpinning the sustainable development of societies (see for example Juang et al., 2016). However, there is also a need to translate this knowledge into practical messages that influence engineering practice and result in development of mitigation/management strategies that can help to ensure that these large-scale engineered interventions in the loess landscape do not result in the manifestation of a wide range of geohazards and thus provide a costly legacy for future
Commented [TD15]: I have significantly shortened this section as there was a lot of repeating. If you feel I have deleted too much, please feel free to undelete. 
generations; at best in terms of potentially expensive remediation, or worse through loss of lives and livelihoods. There remain therefore significant opportunities for engineering geologiststo continue to contribute to achieving sustainable development in the Loess Plateau.

\section{Acknowledgements?}

\section{References}

Assallay, A.M., Rogers, C.D.F. and Smalley, I.J., 1997. Formation and collapse of metastable particle packings and open structures in loess deposits. Engineering Geology, 48(1-2), 101-115.

Chen, H.J., Han, Z.F., Zhou, C.M., Zhang, X.W., 2017. Stability Analysis of High Slope in Loess Cut under Rainfall. Highway, 2, 6-11 (in Chinese).

Chen, H.X., Wang, J.D., 2014. Regression analyses for the minimum intensity-duration conditions of continuous rainfall for mudflows triggering in Yan'an, northern Shaanxi, China. Bulletin of Engineering Geology and the Environment, 73(4), 917-928.

Chen, G., Zhang, Y., Zeng, R.Q., Yang, Z.K., Chen, X., Zhao, F.M., Meng, X.M., 2018. Detection of land subsidence associated with land creation and rapid urbanization in the Chinese Loess Plateau using time series InSAR: A case study of Lanzhou New District. Remote Sensing, 10(2), 270, 23p.
Commented [TD16]: can write this when we get comments back from reviewers....? 
Chinese Academy of Sciences, 1975.http://www.cas.cn/

Close, U., McCormick, E., 1922. Where the Mountains Walked. The National Geographic Magazine, 12 (5).

Colesanti C., Wasowski, J. 2006. Investigating landslides with space-borne Synthetic Aperture Radar (SAR) interferometry. Engineering Geology, 88, 173-199.

Derbyshire, E., 2001. Geological hazards in loess terrain, with particular reference to the loess regions of China. Earth Science Reviews, 54(1-3), 231-260.

Derbyshire, E, Dijkstra T.A., Smalley, I.J. (eds.) 1995. Genesis and properties of collapsible soils. NATO ASI Series C; Mathematical and Physical Sciences, Vol 468. Springer Science and Business Media, Dordrecht, 412p.

Derbyshire, E., Dijkstra, T.A., Smalley, I.J., Li, Y., 1994. Failure mechanisms in loess and the effects of moisture content changes on remolded strength. Quaternary International, 24, $5-15$.

Derbyshire, E.,Mellors, T.W., 1988. Geological and geotechnical characteristics of some loess and loessic soils from China and Britain: a comparison. Engineering Geology, 25(2-4), pp.135-175.

Derbyshire, E., Meng, X.M., Dijkstra, T., 2000. Landslides in the Thick Loess Terrain of North-West China. John Wiley and Sons Ltd, London. 
Dijkstra, T., 1994. Wastewater disposal and problem soils in Lanzhou, China. In Affordable Water Supply and Sanitation. Proceedings $20^{\text {th }}$ WEDC Conference, Colombo, Sri Lanka, 305309.

Dijkstra, T.A, Rogers C.D.F., Smalley I.J., Derbyshire, E., Li, Y.J., Meng, X.M., 1994. The loess of north-central China: Geotechnical properties and their relation to slope stability. Engineering Geology, 36, 153 - 171.

Dijkstra, T.A., Smalley, I.J. and Rogers, C.D.F., 1995. Particle packing in loess deposits and the problem of structure collapse and hydroconsolidation. Engineering Geology, 40(12), 49-64.

Dijkstra, T.A., Wasowski, J., Winter, M.G., Meng, X.M., 2014. Introduction to Geohazards of Central China. Q. J. Eng. Geol. Hydrogeol., 47 (3), 195-199.

Eltner, A., Baumgart, P., Maas, H., \& Faust, D. (2015). Multi-temporal UAV data for automatic measurement of rill and interrill erosion on loess soil. Earth Surface Processes \& Landforms, 40(6), 741-755.

Follmer, L.R., 1996. Loess studies in central United States: Evolution of concepts. Engineering Geology, 45(1-4), 287-304.

Fredlund, D. G., Rahardjo, H., 1993. Soil mechanics for unsaturated soils. John Wiley \& Sons, New Jersey. 
Gao, G.R., 1988. Formation and development of the structure of collapsing loess in China. Engineering Geology, 25(2), 235-245.

Haase, D., Fink, J., Haase, G., Ruske, R., Pécsi, M., Richter, H., Altermann, M. and Jäger, K.D., 2007. Loess in Europe - its spatial distribution based on a European Loess Map, scale 1: 2,500,000. Quaternary Science Reviews, 26(9-10), 1301-1312.

Ho, P.T., 1969. The loess and the origin of Chinese agriculture. The American Historical Review, 75(1), 1-36.

Hu, R.L., Yeung, M.R., Lee, C.F., Wang, S.J., 2001. Mechanical behavior and microstructural variation of loess under dynamic compaction. Engineering Geology, 59(3-4), 203-217.

Hu, S., Qiu, H.J., Wang, X.G., Gao, Y., Wang, N.L., Wu, J., Yang, D.D., Cao, M.M., 2017. Acquiring high-resolution topography and performing spatial analysis of loess landslides by using low-cost UAVs. Landslides, 2, 1-20.

Hungr, O., Leroueil, S. and Picarelli, L., 2014. The Varnes classification of landslide types, an update. Landslides, 11(2), pp.167-194.

Jefferson, I.F., Evstatiev, D., Karastanev, D., Mavlyanova, N.G. and Smalley, I.J., 2003. Engineering geology of loess and loess-like deposits: a commentary on the Russian literature. Engineering Geology, 68(3-4), 333-351. 
Jia, Y.J., 2016. Research on concrete retaining wall reinforced unsaturated loess slope. China Building Materials Science and Technology, 25(4), 107-108 (in Chinese).

Jiang, M.J., Zhang, F.G., Hu, H.J., Cui, Y.J., Peng, J.B., 2014. Structural characterization of natural loess and remolded loess under triaxial tests. Engineering Geology, 181, 249260.

Juang, C.H., Carranza-Torres, C., Crosta, G., Dong, J.J., Gokceoglu, C., Jibson, R.W., Shakoor, A., Tang, H., van Asch, T.W.J., Wasowski, J., 2016. Engineering geology: a fifty-year perspective. Engineering Geology, 201, 67-70.

Leng, Y., Peng, J., Wang, Q., Meng, Z., Huang, W., 2018. A fluidized landslide occurred in the Loess Plateau: a study on loess landslide in South Jingyang Tableland. Engineering Geology, 236, 129-136.

Li, P.Y, Qian, H., Wu, J.H., 2014. Accelerate research on land creation. Nature Comment, $510,29-31$.

Li, Z.H., Motagh, M., Yu, J., Gong, X.L., Wu, J.Q., Zhu, Y.F., Chen, H.G., Zhang, D.M., Xu, Y.L., 2014. Land subsidence in the Yangtze River Delta, China revealed from multifrequency SAR Interferometry.EGU General Assembly.

Liang, C., Cao, C., Wu, S. 2018. Hydraulic-mechanical properties of loess and its behavior when subjected to infiltration-induced wetting. Bulletin of Engineering Geology and the

Commented [U17]: this is just an abstract - I do not think it is needed

Commented [TD18]: My suggestion is to leave it in - it gives people a route to access more information? 
Liu, S.H., 2015. Loess slope engineering: theory and practice on the stability of slope surface. Science Press, Beijing (in Chinese).

Liu, T.S., 1985. Loess and the environment. Science Press, Beijing (in Chinese).

Liu, Y., Liu, N.N., 2017. Research on longitudinal stress mechanism of metro tunnel under ground fissure environment. Journal of Xi'an University (Natural Science Edition), 5, 105-108 (in Chinese).

Luo, H., Wu, F.Q., Chang, J.Y., Xu, J.B., 2018. Microstructural constraints on geotechnical properties of Malan Loess: A case study from Zhaojiaan landslide in Shaanxi province, China. Engineering Geology. 236, 60-69.

Lutenegger, A., (ed.) 1988. Loess Geotechnology; Special Issue. Engineering Geology, 25(24)

Meng, X.M., Xu, Y.H., Guo, T., Zhang, S.W., 1991. Research of Jiaoshuwan and Taishanmiao landslides in Tianshui city. Journal of Gansu Science, 3(2), 36-43 (in Chinese).

MONR, 2012. http://www.mlr.gov.cn/xwdt/mtsy/people//201212/t20121204_1162174.htm (in Chinese; Google translation available).

Nouaouria, M.S., Guenfoud, M. and Lafifi, B., 2008. Engineering properties of loess in Algeria. Engineering Geology, 99(1-2), pp.85-90. 
Pacific Construction Group (PCG), 2014, http://www.cpcg.com.cn/en/industry/golden/201405-28/1401270531d2391.shtml.

Peng, D.L., Xu, Q., Liu, F.Z., He, Y.S., Zhang, S., Qi, X., Zhao, K.Y., Zhang, X.L., 2018a. Distribution and failure modes of the landslides in Heitai terrace, China. Engineering Geology. 236, 97-110.

Peng, J.B., 2012. Geo-Hazards of Xi'an Ground Fissures. Science Press, Beijing (in Chinese).

Peng, J.B., Chen, L.W., Huang, Q.B., Men, Y.M., Fan, W., Yan, J.K., 2013. Physical simulation of ground fissures triggered by underground fault activity. Engineering Geology. 155(2), 19-30.

Peng, J.B., Chen, L.W., Huang, Q.B., Men, Y.M., Fan, W., Yan, J.K., Li, K., Ji, Y.S., Shi, Y.L., 2008. Large-scale physical simulative experiment on ground-fissure expansion mechanism. Chinese Journal of Geophysics, 51(6), 1826-1834.

Peng, J.B., Fan, W., Li, X.A., Wang, Q.L., Feng, X.J., Zhang, J., Li, X.S., Lu, Q.Z., Huang, Q.B., Ma, R.Y., Lu, Y.D., 2007. Some key questions in the formation of ground fissures in the Fen-wei Basin. Journal of Engineering Geology, 15(4), 433-440 (in Chinese).

Peng, J.B., Fan, Z.J., Wu, D., Zhuang, J.Q., Dai, F.C., Chen, W.W., Zhao, C., 2015. Heavy rainfall triggered loess-mudstone landslide and subsequent debris flow in Tianshui, China. Engineering Geology. 186, 79-90. 
Peng, J.B., He, K., Tong, X., Huang, Q.B., Liu, C., 2017a. Failure mechanism of an underground metro tunnel intersecting steep ground fissure at low angle. International Journal of Geomechanics, 17(5), E4016006.

Peng, J.B., Huang, Q.B., Hu, Z.P., Wang, M.X., Li, T., Men, Y.M., Fan, W., 2017a. A proposed solution to the ground fissure encountered in urban metro construction in Xi'an, China. Tunnelling and Underground Space Technology, 61, 12-25.

Peng, J.B., Leng, Y.Q., Zhu, X.H., Wu, D., Tong, X., 2016b. Development of a loessmudstone landslide in a fault fracture zone. Environmental Earth Sciences, 75(8), 658.

Peng, J.B., Lin, H.Z., Wang, Q.Y., Zhuang, J.Q., Cheng, Y.X., Zhu, X.H., 2014. The critical issues and creative concepts in mitigation research of loess geological hazards. Journal of Engineering Geology, 22(4), 684-691 (in Chinese).

Peng, J.B., Ma, P.H., Wang, Q.Y., Zhu, X.H., Zhang, F.Y., Tong, X., Huang, W.L., 2018a. Interaction between landsliding materials and the underlying erodible bed in a loess flow slide. Engineering Geology. 234, 38-49.

Peng, J.B., Sun, P., Igwe, O., Li, X.A., 2017b. Loess caves, a special kind of geo-hazard on loess plateau, northwestern China. Engineering Geology, 236. 79-88.

Peng, J.B., Sun, X.H., Wang, W., Sun, G.C., 2016c. Characteristics of land subsidence, earth fissures and related disaster chain effects with respect to urban hazards in Xi'an, China. Environmental Earth Sciences, 75(16), 136-146. 
Peng, J.B., Wang, G.H., Wang, Q.Y., Zhang, F.Y., 2017c. Shear wave velocity imaging of landslide debris deposited on an erodible bed and possible movement mechanism for a loess landslide in Jingyang, Xi’an, China. Landslides, 14, 1503-1512.

Peng, J.B., Wu, D., Duan, Z., Tang, D.Q., Cheng, Y.X., Che, W.Y., Huang, W.L., Wang, Q.Y., Zhuang, J.Q., 2016d. Disaster characteristics and destructive mechanism of typical loess landslide cases triggered by human engineering activities. Journal of Southwest Jiaotong University, 51, 971-980 (in Chinese).

Peng, J.B., Xu, J.S., Ma, R.Y., Wang, F.Y., 2016e. Characteristics and mechanism of the Longyao ground fissure on North China Plain, China. Engineering Geology, 214,136146.

Peng, J.B., Zhang, F.Y., Wang, G.H., 2017d. Rapid loess flow slides in Heifangtai terrace, Gansu, China. Quarterly Journal of Engineering Geology and Hydrogeology, 50, 106110.

Peng, J.B., Zhuang, J.Q., Wang, G.H., Dai, F.C., Zhang, F.Y., Huang, W.L., Xu, Q., 2018b. Liquefaction of loess landslides as a consequence of irrigation. Quarterly Journal of Engineering Geology and Hydrogeology, DOI: qjegdoi.org/10.1144/qjegh2017-098.

Picarelli, L., 2010. Discussion on "A rapid loess flow slide triggered by irrigation in China" by D. Zhang, G. Wang, C. Luo, J. Chen, and Y. Zhou. Landslides. 7(2), 203-205. 
Qi, X., Xu, Q., Liu, F.Z., 2018. Analysis of retrogressive loess flow slides in Heifangtai, China. Engineering Geology. 236, 119-128.

Richthofen, F. von, 1877. China. Ergebnisse eigener Reisen unddaran gegruendeter Studien, $1,392 \mathrm{p}$

Rogers, C.D.F., Dijkstra, T.A. and Smalley, I.J., 1994. Hydroconsolidation and subsidence of loess: studies from China, Russia, North America and Europe: in memory of Jan Sajgalik. Engineering Geology, 37(2), 83-113.

Scheidig, A., 1934. Löss und seine geotechnischen eigenschaften.Steinkopf, Dresden und Leipzig, 233p.

Smalley, I., 1995. Making the material: the formation of silt sized primary mineral particles for loess deposits. Quaternary Science Reviews, 14(7-8), 645-651.

Smalley, I.J., Jefferson, I.F., Dijkstra, T.A. and Derbyshire, E., 2001. Some major events in the development of the scientific study of loess. Earth-Science Reviews, 54(1-3), 5-18.

Smalley, I.J. and Smalley, V., 1983. Loess material and loess deposits: formation, distribution and consequences. In Developments in Sedimentology (Vol. 38, pp. 51-68). Elsevier.

Shi, J.S., Wu, L.Z., Wu, S.R., Li, B., Wang, T., Xin, P., 2016.Analysis of the causes of largescale loess landslides in Baoji, China. Geomorphology. 264, 109-117.

Svendsen, J.I., Alexanderson, H., Astakhov, V.I., Demidov, I., Dowdeswell, J.A., Funder, S., Gataullin, V., Henriksen, M., Hjort, C., Houmark-Nielsen, M., Hubberten, H.W. et al., 
2004. Late Quaternary ice sheet history of northern Eurasia. Quaternary Science Reviews, 23(11-13), 1229-1271.

Tan, T.K., 1988.Fundamental properties of loess from North-western China. Eng. Geol., 25, 103-133.

Trofimov, V.T., Balykova, S.D. and Bolihovskaya, N.S., 2001. Loess cover of the earth and its properties. MSU, Moscow, 464. (in Russian)

Trofimov, V.T., Balykova, S.D., Andreeva, T.V., Ershova, A.V., 2015. Subsidence of buried soils in cyclic loess sequences of the northern Eurasia. In Engineering Geology for Society and Territory-Volume 5 (pp. 439-442). Springer, Cham.

Tu, X.B., Kwong, A.K.L., Dai, F.C., Tham, L.G., Min, H., 2009. Field monitoring of rainfall infiltration in a loess slope and analysis of failure mechanism of rainfall-induced landslides. Engineering Geology, 105(1-2), 134-150.

Varnes, D.J., 1978. Slope movement types and processes. Special report, 176, pp.11-33.

Vasiljević, D.A., Marković, S.B., Hose, T.A., Ding, Z., Guo, Z., Liu, X., Smalley, I., Lukić, T. and Vujičić, M.D., 2014. Loess-palaeosol sequences in China and Europe: common values and geoconservation issues. Catena, 117, 108-118.

Wang G.A.,HanJ.M.,Liu D.S.,2003. The carbon isotope composition of C3 herbaceous plants in loess area of northern China.Science in China,46 (10),1069-1076. 
Wang, G.X., 1997. Sliding mechanism and prediction of critical sliding of Huangci landslide in Yongjing county, Gansu province. Journal of Catastrophology, 3, 23-27 (in Chinese).

Wang, G.H., Zhang, D.X., Furuya, G., Yang, J., 2014. Pore-pressure generation and fluidization in a loess landslide triggered by the 1920 Haiyuan earthquake, China: A case study. Engineering Geology. 174(1), 36-45.

Wang, H.B., Zhou, B., Wu, S.R., Shi, J.S., Li, B., 2011. Characteristic analysis of large-scale loess landslides: a case study in Baoji City of Loess Plateau of Northwest China. Natural Hazards and Earth System Sciences, 11(7), 1829-1837.

Wang, W., Wang, Y., Sun, Q., Zhang, M., Qiang, Y., Liu, M., 2018. Spatial variation of saturated hydraulic conductivity of a loess slope in the South Jingyang Plateau, China. Engineering Geology. 236, 70-78.

Wang,Y.Q., Shao,M., Shao. H.B., 2010. A preliminary investigation of the dynamic characteristics of dried soil layers on the Loess Plateau of China.Journal of Hydrology, $381(1), 9-17$.

Wasowski, J., Bovenga, F., 2014. Investigating landslides and unstable slopes with satellite Multi Temporal Interferometry: current issues and future perspectives. Engineering Geology, 174, 103-138.

Wasowski, J., Bovenga, F., 2015. Remote sensing of landslide motion with emphasis on satellite multitemporal interferometry applications: an overview. In: Davies, T. 
(Ed.),Landslide Hazards, Risks and Disasters, pp. 345-403.

http://dx.doi.org/10.1016/B978-0-12-396452-6.00011-2.

Wasowski, J., Bovenga, F., Dijkstra, T., Meng, X., Nutricato, R., Chiaradia, M.T., 2014.

Persistent scatterers interferometry provides insight on slope deformations and landslide activity in the mountains of Zhouqu, Gansu, China. In: Sassa, K. (Ed.), Landslide Science for a Safer Geoenvironment, Vol. 2: Methods of Landslide Studies. Springer International Publishing, pp. 359-364. http://dx.doi.org/10.1007/978-3- 319-05050-8_56.

Wasowski, J., Bovenga, F., Nitti, D.O., Nutricato, R. Dijkstra, T., Meng X. 2012.PSI helps to map relative susceptibility to ground and slope instabilities in the Lanzhou loess area of Gansu Province, China. Proceedings of Fringe 2011 Workshop, Frascati, Italy, ESA Special Publication 697. (CD-ROM), ISSN: 1609-142X

Wu, Q., Chen, P.P., 2005. A "Three Maps" Method on the Evaluations of Ground Fissure Hazard. Acta Geologica Sinica. 79(6), 774-783 (in Chinese).

Xu, L., Coop, M. R., 2017. The mechanics of a saturated silty loess with a transitional mode. Geotechnique, 67(7):1-16.

Xu, L., Coop, M.R., Zhang, M.S., Wang, G.L., 2018. The mechanics of a saturated silty loess and implications for landslides. Engineering Geology. 236(26), 29-42. 
Xu, L., Dai, F.C., Gong, Q.M., Tham, L.G., Min, H., 2012a. Irrigation-induced loess flow failure in Heifangtai platform, north-west China. Environmental Earth Sciences. 66(6), 1707-1713.

Xu, L., Dai, F.C., Tham, L.G., Tu, X.B., Jin, Y.L., 2011. Landslides in the transitional slopes between a loess platform and river terrace, northwest China. Environmental and Engineering Geoscience. 17, 267-279.

Xu, L., Dai, F.C., Tu, X.B., Tham, L.G, Zhou, Y.F., Iqbal, J., 2014. Landslides in a Loess Platform, North-West China. Landslides, 11(6), 993-1005.

Xu, L., Qiao, X.J., Wu, C.X., Iqbal, J., Dai, F.C., 2012b. Causes of landslide recurrence in a loess platform with respect to hydrological processes, Natural Hazards, 64(2),16571670.

Xue, Y.T., Meng, X.M.,Wasowsk, J., Chen, G., Li, K., Guo, P., Bovenga, F., Zeng, R.Q., 2016. Spatial analysis of surface deformation distribution detected by persistent scatterer interferometry in Lanzhou Region, China. Environ Earth Sci .75 (1),80.

Zárate, M.A., 2003. Loess of southern south america. Quaternary Science Reviews, 22(1819), 1987-2006.

Zeng, R., Meng X., Wasowski J., Dijkstra T., Bovenga F., Xue Y., Wang S., 2014. Ground instability detection using PS-InSAR in Lanzhou, China. Quarterly Journal of 
Engineering Geology and Hydrogeology,47, 307-321.

http://dx.doi.org/10.1144/qjegh2014-040

Zeng, R.Q., Meng, X.M., Zhang, F.Y., Wang, S.Y., Cui, Z.J., Zhang, M.S., Zhang, Y., Chen, G., 2016. Characterizing hydrological processes on loess slopes using electrical resistivity tomography - a case study of the Heifangtai terrace, northwest China. Journal of Hydrology, 541, 742-753.

Zhang, D.,Wang, G., 2007. Study of the 1920 Haiyuan earthquake-induced landslides in loess (China). Engineering Geology, 94(1-2), 76-88.

Zhang, F.Y., Chen, W.W., Liu, G., Liang, S.Y., Kang, C., He, F.G., 2012. Relationships between landslide types and topographic attributes in a loess catchment, China. Journal of Mountain Science, 9(6), 742-751.

Zhang, F.Y., Kang, C., Chan, D., Zhang, X.C., Pei, X.J., Peng, J.B., 2017. A study of a flow slide with significant entrainment in loess areas in China. Earth Surface Processes and Landforms, 42, 2295-2305.

Zhang, F.Y., Wang, G.H., 2018. Effect of irrigation-induced densification on the post-failure behavior of loess flow slides occurring on the Heifangtai area, Gansu, China. Engineering Geology, 236(26), 111-118. 
Zhang, M.S., Cheng, X.J., Dong, Y., Yu, G.Q., Zhu, L.F. and Pei, Y., 2013a. The effect of frozen stagnant water and its impact on slope stability: a case study of Heifangtai, Gansu Province. Geological Bulletin of China, 32(6), pp.852-860.

Zhang, F.Y., Wang, G.H., Kamai, T., Chen, W.W., Zhang, D.X., Yang, J., 2013b. Undrained shear behavior of saturated loess at different concentrations of sodium chlorate solution. Engineering Geology. 155(6), 69-79.

Zhang, Y. Meng, X., Jordan, C., Novellino A., Dijkstra, T., Chen, C. 2018. Investigating slow-moving landslides in the Zhouqu region of China using InSAR time series. Landslides, 15 (7), 1299-1315.

Zhang, Z.L., Wang, T., Wu, S.R., Tang, H.M., Xin, P., Liang, C.Y., 2017. Dynamics stressstrain behavior of Tianshui soils. Landslides, 14(1), 323-335.

Zhao, CY., Zhang, Q., He, Y.,Peng, J.B., Yang, C.S.,Kang, Y., 2016. Small-scale loess landslide monitoring with small baseline subsets interferometric synthetic aperture radar technique - case study of Xingyuan landslide, Shaanxi, China. J Appl Remote Sens. 10(2), 026030 .

Zhao, D., Xu, M.X., Liu, G.B., Ma, L.Y., Zhang, S.M., Xiao, T.Q., Peng, G.Y., 2017. Effect of vegetation type on microstructure of soil aggregates on the Loess Plateau, China. Agriculture, Ecosystems and Environment, 242, 1-8. 
Zheng, Y., 2017. Nine hours early warning of landslide in a slope made by Chengdu University of Technology that have a distance of thousands of miles between them. http://news.chengdu.cn/2017/1011/1919068.shtml. (in Chinese).

Zhuang, J.Q., Iqbal, J., Peng, J.B., Liu, T.M., 2014a. Probability prediction model for landslide occurrences in Xi'an, Shaanxi Province, China. Journal of Mountain Science, 11(2), 345-359.

Zhuang, J.Q., Peng, J.B., 2014b. A coupled slope cutting-a prolonged rainfall-induced loess landslide: a 17 October 2011 case study. Bulletin of Engineering Geology and the Environment, 73(4), 997-1011.

Zhuang, J.Q., Peng, J.B., Wang, G.H., Iqbal, J., Wang, Y., Li, W., Xu, Q., Zhu, X.H., 2017. Prediction of rainfall-induced shallow landslides in the Loess Plateau, Yan'an, China, using the TRIGRS model. Earth Surface Processes and Landforms, 42(6), 915-927.

Zhuang, J.Q., Peng, J.B., Wang, G.H., Javed, I., Wang, Y., Li, W., 2018a. Distribution and characteristics of landslide in Loess Plateau: A case study in Shaanxi province. Engineering Geology, 236, 89-96.

Zhuang, J., Peng, J., Xu, C., Li, Z., Densmore, A., Milledge, D., Iqbal, J. Cui, Y., 2018b. Distribution and characteristics of loess landslides triggered by the 1920 Haiyuan Earthquake, Northwest of China. Geomorphology, 314, 1-12. 